\title{
INFLUENCE OF LIGHT CURING SOURCE ON MICROHARDNESS OF COMPOSITE RESINS OF DIFFERENT SHADES
}

\author{
INFLUENCIA DA FONTE DE LUZ POLIMERIZADORA NA MICRODUREZA \\ DA RESINA COMPOSTA DE DIFERENTES CORES
}

\begin{abstract}
André Luiz Fraga BRISO ${ }^{1}$, Tânia Maria FEDEL ${ }^{2}$, Sibéria de Morais PEREIRA², Sílvio José MAURO루, Renato Herman SUNDFELD ${ }^{3}$, Maria Lúcia Marçal Mazza SUNDEFELD ${ }^{1}$
\end{abstract}

\begin{abstract}
1- DDS, MS, PhD - Assistant Professor - Department of Restorative Dentistry of Araçatuba Dental School - State University of São PauloUNESP - Araçatuba - Brazil.

2- Undergraduate student of Araçatuba Dental School - UNESP - Brazil. Research grant from FAPESP - Process n. 03/06797-6.

3- DDS, MS, PhD - Associate Professor - Department of Restorative Dentistry of Araçatuba Dental School - State University of São PauloUNESP - Araçatuba - Brazil.
\end{abstract}

Corresponding address: Prof. Dr. André Luiz Fraga Briso - Department of Restorative Dentistry, - UNESP, Rua José Bonifácio 1193 Cep.: 16015 050, Araçatuba, São Paulo, Brazil. - Fax: 55-018 36363251 - e-mail: alfbriso@foa.unesp.br

Received: February 22, 2005 - Modification: August 30, 2005 - Accepted: October 27, 2005

\begin{abstract}
I

ntroduction: The evolution of light curing units can be noticed by the different systems recently introduced. The technology of LED units promises longer lifetime, without heating and with production of specific light for activation of camphorquinone. However, further studies are still required to check the real curing effectiveness of these units. Purpose: This study evaluated the microhardness of 4 shades (B-0.5, B-1, B-2 and B-3) of composite resin Filtek Z-250 (3M ESPE) after light curing with 4 light sources, being one halogen (Ultralux Dabi Atlante) and three LED (Ultraled - Dabi Atlante, Ultrablue - DMC and Elipar Freelight - 3M ESPE). Methods: 192 specimens were distributed into 16 groups, and materials were inserted in a single increment in cylindrical templates measuring $4 \mathrm{~mm} \mathrm{x} 4 \mathrm{~mm}$ and light cured as recommended by the manufacturer. Then, they were submitted to microhardness test on the top and bottom aspects of the cylinders. Results: The hardness values achieved were submitted to analysis of variance and to Tukey test at $5 \%$ confidence level. It was observed that microhardness of specimens varied according to the shade of the material and light sources employed. The LED appliance emitting greater light intensity provided the highest hardness values with shade B-0.5, allowing the best curing. On the other hand, appliances with low light intensity were the least effective. It was also observed that the bottom of specimens was more sensitive to changes in shade. Conclusion: Light intensity of LED light curing units is fundamental for their good functioning, especially when applied in resins with darker shades. Uniterms: Microhardness; Curing equipment; Composite resins; Shades
\end{abstract}

\footnotetext{
RESUMO

$I$

ntroduction: A evolução dos aparelhos fotopolimerizadores pode ser notada nos diferentes sistemas introduzidos recentemente no mercado. A tecnologia apresentada pelos aparelhos LED promete maior tempo de vida útil, não gerar aquecimento e produzir luz específica para a ativação da canforoquinona. No entanto, ainda são necessários estudos complementares para se conhecer a real efetividade destes aparelhos na polimerização dos materiais. Proposta: Neste trabalho foi verificada a microdureza de 4 cores (B-0,5, B-1, B-2 e B-3) da resina composta Filtek Z-250 (3M ESPE) quando polimerizadas com 4 fontes de luz, sendo uma halógena (Ultralux - Dabi Atlante) e três LED (Ultraled - Dabi Atlante, Ultrablue - DMC e Elipar Freelight - 3M ESPE). Métodos: Os 192 corpos-de-prova foram distribuídos em 16 grupos e os materiais foram inseridos em único incremento em matrizes cilíndricas de $4 \mathrm{~mm} X \mathrm{Xmm}$, sendo polimerizados pelo tempo preconizado pelo fabricante. Em seguida, foram submetidos ao teste de microdureza na superfície superior e inferior dos cilindros. Resultados: Os valores de dureza obtidos foram submetidos à análise de variância e ao teste de Tukey ao nível de 5\%. Foi observado que a dureza dos corpos-de-prova variou conforme a cor do material e aparelhos utilizados. O aparelho LED que emite maior intensidade luminosa proporcionou a obtenção dos maiores valores de dureza, com o croma B-0,5 possibilitando a melhor polimerização. Por outro lado aparelhos com baixa intensidade luminosa foram os menos efetivos. Também foi observado que a região do fundo dos corpos-de-prova foi mais sensível à mudança das cores. Conclusões: A intensidade de luz dos fotopolimerizadores LED é fundamental para seu bom funcionamento, principalmente quando empregadas resinas com croma mais acentuado.

Unitermos: Microdureza; Fotopolimerizadores; Resinas compostas; Cores
} 


\section{INTRODUCTION}

The use of composite resins has appeared in Dentistry as a response to the expectations to achieve a material that might fulfill the requirements of the oral environment and also allow achievement of restorations with proper function and especially esthetics ${ }^{19}$.

Light cured composite resins offer several advantages compared to early restorative systems, and their curing depends on application of light on their surface ${ }^{11,27}$.

Curing depth is often considered a primary factor for clinical success of composite resin restorations, since it directly affects the physical properties of materials and longevity of restorations.

The factors that may affect the curing of resin materials according to the literature $e^{7,17,25,28}$ include those directly related to the restorative material, including composite resin shade, amount of photoinitiators, organic and filler matrixes. Similarly, light curing units also play a fundamental role for proper curing, especially concerning the period of exposure and general status of the equipment.

Therefore, in an attempt to optimize the utilization of light cured composites, manufacturers of light curing units have developed different curing systems, including those with soft start mechanism, which gradually increase light intensity, and those that emit a constant light intensity higher than $1,000 \mathrm{~mW} / \mathrm{cm}^{2}$. Later, light emitting diode (LED) light curing units were developed, which apply a lower light intensity than conventional light curing units, yet are able to cure resin materials, because of light emission in specific wavelength for activation of camphorquinone (450 to $480 \mathrm{~nm})^{10,14}$.

However, Pires, et al. ${ }^{21}$ (1993), employing halogen light curing units, observed a strong correlation between light intensity and microhardness, revealing a small depth of curing or reduction in microhardness values when the light intensity applied to the composite was reduced. However, more recent studies (Price et.al., 2004) ${ }^{24}$ revealed that when the energy density $\left(\mathrm{J} / \mathrm{cm}^{2}\right)$ is maintained, the increase in intensity is no related with the curing depth.

Kawaguchi $^{14}$ (1994) investigated halogen light curing units following guidelines of the International Organization Standardization (ISO) DIS 4049, and highlighted that the coefficient of light transmission of different materials also influences their curing, being that some materials may be cured in depth with lower light intensity than others.

Within this context, the factors that may affect the curing of materials include those related to the restorative material, including the resin shade, amount of photoinitiators, organic and inorganic matrix; the operator, including the distance and orientation of light beams and restorative technique; and types of light curing units, concerning the emission spectrum and association between light intensity, period of exposure and general status of the equipment $\mathrm{t}^{1,7,11}$.

Based on these data, doubts have arisen: are LED curing units effective? What is the performance of these units to cure different resin shades? All these factors and doubts indicate the importance to investigate the real curing ability of different light curing systems available in dental market.

Moreover, composite resins currently available are highly complex and technically sophisticated materials. Therefore, to avoid selection of a certain product by the subjective preference of the operator, it is important to understand its physical and mechanical properties, as well as its performance after utilization of different light curing units ${ }^{17}$.

Therefore, the present study evaluated the microhardness of different composite resin shades, after utilization of a halogen light source and three light emitting diode (LED) curing units, considering readings performed on the surface close to the light source and also at $4 \mathrm{~mm}$ in depth. LED units emitting similar wavelengths with different power densities were compared with a conventional halogen light unit that emits a wider light spectrum. The null hypothesis to be tested was that either the shade composite resins or curing equipment would not interfere with the microhardness values.

\section{MATERIALS AND METHODS}

A total of 192 specimens were fabricated, which were distributed into 16 study groups. Specimens were fabricated with aid of acrylic cylindrical templates with a central perforation measuring $4 \mathrm{~mm}$ in diameter and $4 \mathrm{~mm}$ in height.

For fabrication of specimens, templates were positioned on a glass slab and completely filled in a single increment, with some excess, with the composite resin Filtek Z-250 (3M ESPE) of different shades (B-0.5, B-1, B-2 and B-3). Then, a polyester strip (3M ESPE) and another glass slab were positioned on composite resin, with application of force against the composite resin template. After 10 seconds, the top glass slab was removed, the polyester strip was kept in position and each specimen was submitted to the light emitted by the light curing units for 20 seconds, as recommended by the manufacturers. Specimens fabricated with the B-0.5 shade were light cured for 30 seconds, as recommended by the manufacturer for this shade.

Light curing units employed were the Ultraled unit (DabiAtlante), with 7 LEDs and light intensity of $200 \mathrm{~mW} / \mathrm{cm}^{2}$; Ultrablue I unit (DMC), with 7 LEDs and $140 \mathrm{~mW} / \mathrm{cm}^{2}$; Elipar Freelight unit (3M - ESPE), with $19 \mathrm{LEDs}$ and $400 \mathrm{~mW} / \mathrm{cm}^{2}$; and Ultralux halogen light unit (Dabi Atlante) with 380mW/ $\mathrm{cm}^{2}$. All units were measured with radiometer cure Demetron and were connected to a voltage stabilizer Revolution II (SMS) to allow maintenance of their power.

Then, templates filled with composite resin were labeled and marked on the top surface for identification of the region closest to the light source. Thereafter, specimens were cleaned with a detergent solution in ultrasound, Branson 2210, for 10 minutes, to remove debris occasionally accumulated during handling of specimens. For achievement of a surface with no staining, they were rinsed with water spray and dried with absorbent paper.

Surface microhardness of specimens was measured with HMU-2000 Shimadzu, with utilization of a Knoop indenter of $20 \mathrm{~g}$ for $5 \mathrm{~s}$. This way, 3 indents were performed on top 
surface and further 3 on bottom surface, which was more distant from the light source.

Considering that each of the 16 study groups had 12 specimens that received 3 indents, original data comprised 576 microhardness values for each surface. Statistical analysis was performed by calculation of mean values of 3 measurements performed for each surface, adding up to 192 independent data analyzed for the top surfaces and 192 for the bottom surfaces.

Results were submitted to analysis of variance; whenever a significant difference was found, Tukey test at the $5 \%$ level was applied. The software employed was the SAS System, v. 8.2.

\section{RESULTS}

Table 1 presents original microhardness means and standard deviation of each study group with regard to the top and bottom aspects of specimens. Analysis of both surfaces with regard to different light curing units indicated a statistically significant difference for all study groups; Elipar Freelight unit (3M-ESPE) provided highest values of surface hardness, regardless of the composite shade. The lowest values were achieved with the Ultrablue unit (DMC), whereas the Ultralux (Dabi Atlante) and Ultraled units (Dabi Atlante), respectively, presented intermediate results (Tables 2).

However, when the composite resin shades were considered at the top surfaces, groups of B- 0.5 shade presented highest hardness values, whereas other shades presented similar results. On the other hand, for the bottom surfaces, all had a significant effect on the efficacy of the units. Therefore, groups of specimens of B- 0.5 shade presented the highest means, followed by shades B-1, B-2 and B-3, respectively (Table 3).

\section{DISCUSSION}

Currently, there has been considerable emphasis on the concentration of photoinitiators and wavelength employed to cure resin materials, since they are in charge of conversion of monomers into resin polymers, which determine the curing of resin material. It is known that concentration of camphorquinone varies between materials and may be altered according to shade and translucency of the material ${ }^{6}$. Thus, curing of resin materials has been subject of several studies with different methodologies ${ }^{4,5,20}$. These include microhardness test, which is one of the most often employed methods and is able to provide reliable results and reproducibility to the study.

According to Shortall and Harrington ${ }^{26}$ (1996), intrinsic characteristics of each material, as composition, hue and shade, may interfere with the curing depth; an appliance able to transmit adequate light intensity with correct wavelength is required to provide good results ${ }^{11}$.

With regard to the appliances analyzed in the present study, halogen light unit is the most widely employed and, because it works in a wider light spectrum, besides curing the restorative material, it may also heat the tooth and composite resin during the process ${ }^{23}$. These appliances usually work in wavelengths of 400nm to 700nm; however, only wavelength nearly $470 \mathrm{~nm}$ is strongly absorbed by photoinitiator (camphorquinone) ${ }^{23}$.

Period of exposure also plays an important role in the curing process, since the surface hardness of composite resin is significantly increased when exposed for longer periods ${ }^{10,15,26}$. Moreover, Caughman, et al. ${ }^{5}$ (1995) and Feilzer, et al. ${ }^{7}$ (1995) also agree that light intensity, wavelength and time of exposure are critical variables for achievement of maximum curing of composite resins.

Considering these observations, analysis of microhardness values achieved i.e. on the top revealed that Elipar Freelight provided the best outcomes. This may be related to the wavelength emitted by this unit, which according to its manufacturer coincides with the maximum absorption of camphorquinone, explaining its better performance compared to halogen light units. Compared to other LED units tested, Elipar Freelight unit probably was more successful because of the higher light intensity emitted. Within this context, according to Vieira, et al. ${ }^{34}$ (1999) and Briso $^{4}$ (2003), light emission in low intensity yields inadequate light curing of composite resins, even if the time recommended by the manufacturers is followed, and may negatively influence physical properties and clinical performance of these materials.

TABLE 1- Original means of microhardness and standard deviation presented by the study groups on the top and bottom of specimens

\begin{tabular}{lllll}
\hline & \multicolumn{3}{c}{ Top } & \multicolumn{2}{c}{ Bottom } \\
Group & Mean & SD & Mean & SD \\
\hline I & 59.9 & 2.78 & 40.8 & 2.03 \\
II & 57.4 & 2.39 & 40.0 & 1.80 \\
III & 58.4 & 1.57 & 39.8 & 0.70 \\
IV & 58.0 & 1.83 & 37.4 & 1.15 \\
V & 58.2 & 3.62 & 30.7 & 1.38 \\
VI & 55.2 & 3.64 & 28.6 & 1.46 \\
VII & 52.5 & 3.41 & 28.1 & 1.29 \\
VIII & 51.9 & 2.45 & 27.2 & 1.75 \\
IX & 54.2 & 1.92 & 32.1 & 0.62 \\
X & 46.6 & 1.15 & 29.4 & 1.15 \\
XI & 43.9 & 2.07 & 26.7 & 2.52 \\
XII & 44.5 & 2.30 & 22.7 & 1.64 \\
XIII & 60.6 & 1.39 & 42.8 & 1.16 \\
XIV & 60.2 & 3.27 & 42.2 & 1.52 \\
XV & 61.8 & 1.95 & 40.4 & 0.89 \\
XVI & 61.6 & 1.58 & 41.4 & 0.98 \\
\hline & & & &
\end{tabular}


Similarly, Ultralux unit presented better performance than Ultraled and Ultrablue units because of higher light intensity. The lower mean hardness values found for Ultraled and Ultrablue units, which are also LED units, are assigned to lower light intensity emitted and improper wavelength for curing composite resins employed. Frentzen, et al. ${ }^{9}$ (2001) compared a halogen light unit and a LED unit and reported that LED unit achieved higher hardness values; however, authors did not mention the light intensity emitted by the units, which impairs comparison with the present results.

Studies as that conducted by Pereira, et al. ${ }^{20}$ (2001) corroborate the present findings, concluding that units emitting higher light intensities have a stronger ability of curing and thereby allow achievement of higher hardness values. These aspects may also be taken into account for analysis of the Ultrablue unit, which was less effective than all other units tested.

Bosquiroli $^{3}$ (2003) highlighted that resins may have different photoinitiators, and thus the emission spectrum of the equipment may be na important factor for the final properties of restorations. According to the author, the energy required for each composite should be indicated on the label, and similarly the light curing units should indicate the light intensity emitted and corresponding wavelength. These observations are extremely relevant for LED units applied on materials containing camphorquinone as photoinitiator. However, other photoinitiators require energy at other wavelengths and in these cases some units currently available will not effectively cure these materials ${ }^{32}$.

When the influence of shade on microhardness is individually considered, the results demonstrate that shade B-0.5 presented higher values than other shades. This is primarily related to the period of exposure suggested by manufacturer, which is 10 seconds more than recommended for shades B-1, B-2 and B-3. According to Baharav, et al. ${ }^{1}$ (1997) and Pereira, et al. ${ }^{19}$ (2000), the time of exposure to light is the most significant aspect influencing higher hardness values and consequently greater curing depth.

There was also significant reduction in microhardness on the bottom aspect of specimens in all study groups. Despite of that, in general the bottom aspect presented the same tendency observed at the top surface, i.e. units with higher light intensities (Elipar Freelight and Ultralux, respectively), were better than the others (Ultraled and Ultrablue), with a statistically significant difference in the performance of all units. It should be highlighted that low light intensities may only cure composite superficially, therefore impairing the clinical performance of restorations and giving the false impression that the material is well cured $^{1}$. This information was demonstrated by the observation that, on the bottom surface of specimens, the composite shade influenced the performance of units.

Thus, on the bottom surface, shade B-0.5 provided higher hardness values, followed by resins B-1, B-2 and B3 , respectively. This was probably due to the distance from light source, as well as because the curing depth is inversely proportional to hue value. Therefore, darker materials possibly impair light penetration into the deepest regions of specimens, as also observed by Tanoue et al. ${ }^{29}$ (2001). Considering the means achieved by the groups, this effect seems to be more significant in specimens submitted to units that emit lower light intensities (G-VIII and G-XII).

This was also noticed by Ferracane, et al. ${ }^{8}$ (1997), who related the curing depth of different composite resins to

TABLE 2- Results of Tukey test for analysis of performance of light curing units tested in top and bottom surfaces

\begin{tabular}{|c|c|c|c|c|c|}
\hline Light source & Manufacturer & Top Mean & Decision & Bottom Mean & Decision \\
\hline Elipar Freelight & 3M-ESPE & 61.0 & A & 41.7 & A \\
\hline Ultralux & Dabi Atlante & 58.4 & B & 40.0 & $\mathrm{~B}$ \\
\hline Ultraled & Dabi Atlante & 54.5 & C & 28.7 & C \\
\hline Ultrablue & DMC & 47.3 & $\mathrm{D}$ & 27.7 & $\mathrm{D}$ \\
\hline
\end{tabular}

DMS (top) $=0.0235 \quad$ DMS (bottom) $=0.0242$

TABLE 3- Results of Tukey test for analysis of hardness presented by different shades of composite resin investigated in top and bottom surfaces

\begin{tabular}{lllll}
\hline Shade & Top Mean & Decision & Bottom Mean & Decision \\
\hline B-0.5 & 58.2 & A & 37.1 & A \\
B-1 & 54.8 & B & 35.1 & B \\
B-2 & 54.1 & B & 33.8 & C \\
B-3 & 53.9 & B & 32.2 & D \\
\hline
\end{tabular}

DMS (top) $=0.0235$

DMS (bottom) $=0.0242$ 
shade and translucency of materials, concluding that lighter shades allow greater curing depth. In fact, the present results are in agreement with the findings of Cook and Standish ${ }^{6}$ (1983) and Kanca III $^{13}(1986)$ who stated that pigments employed to provide shades to restorative materials may absorb the light passing through the resin and impair curing. These pigments probably act as selective filters for certain light wavelengths. Studies conducted by Pollack and Lewis ${ }^{22}$ (1981), Thirta, et al. ${ }^{30}$ (1982), Cook and Standish ${ }^{6}$ (1983) and Swartz, et al. ${ }^{27}$ (1983), also reveal that light cured composite resins of dark shades require longer periods of exposure, and curing in thinner layers is recommended to allow higher hardness values.

However, despite the present considerations, it should be highlighted that Lohbauer, et al. ${ }^{16}$ (2005) tested several photoinitiator equipments and stated that conventional halogen light units allow less loss of mechanical properties of dental composites, even though LED units have been presenting encouraging outcomes when employed with compatible resin materials inserted with proper thickness $2,12,18,31,33$.

Thus, it seems evident that selection of light curing unit should be considered an important step to conduct clinical work with resin materials. It should also be mentioned that many types of units are introduced in the market every year, whose manufacturers state their proved efficiency, low cost and easy maintenance. However, professionals should base their decisions in well-designed scientific studies, besides searching for constant update, not being limited to reading folders and technical profiles supplied by manufacturers and/or representatives. These aspects demonstrate that correct selection should be based on impartial studies, and materials introduced in the market may not have been adequately tested for utilization in the dental clinic.

\section{CONCLUSIONS}

On the basis of results achieved, the following could be concluded:

- In both LED and halogen light units, the microhardness values ranged according to the shade of resin and appliances employed;

- Shade was inversely proportional to the surface hardness of resin, with the highest values observed for shade B-0.5;

- LED units with low light intensity provided lower hardness values than high intensity units;

-Aspects distant from the light source were more sensitive to changes in shades.

- The emission of light at a specific wavelength for activation of camphorquinone by a unit did not lead to successful curing of the materials investigated.

\section{ACKNOWLEDGEMENTS}

This research was supported by Fapesp grant n. 03/ 06797-6, São Paulo, Brazil.

\section{REFERENCES}

1- Baharav H, Brosh T, Pilo R, Cardash H. Effect of irradiation time on tensile properties of stiffness and strength of composites. J Prosthet Dent. 1997;77:471-4.

2- Bala O, Ölmez A, Kalayci S. Effect of LED and halogen light curing on polymerization of resin-based composites. J Oral Rehabil. 2005;32:134-40.

3- Bosquiroli V. Avaliação da resistência à tração de uma resina composta fotopolimerizável em função de diferentes fontes de luz e de tempos de ativação. Bauru; 2003. [Dissertação de Mestrado Faculdade de Odontologia de Bauru - USP].

4- Briso ALF, Sundfeld RH, Costa SAC, Lima JM, Campos IT. Avaliação da intensidade luminosa produzida por unidades fotoativadoras e grau de satisfação dos profissionais em emprega-las. JBC J Bras Dent Estet. 2003;2:212-6.

5- Caughman WF, Rueggeberg FA, Curtis JW Jr. Clinical guidelines for photocuring restorative resins. J Am Dent Assoc. 1995;126:1280-2, 1284, 1286 .

6- Cook WD, Standish PM. Cure of resin based restorative materials. White light photopolymerized resin. Aust Dent J. 1983;28: 307-11.

7- Feilzer AJ, Dooren LH, De Gee AJ, Davidson CL. Influence of light intensity on polymerization shrinkage and integrity of restoration-cavity interface. Eur J Oral Sci. 1995;103:322-6.

8- Ferracane JL, Mitchem JC, Condon JR, Todd R. Wear and marginal breakdown of composites with various degrees of cure. J Dent Res. 1997;76:1508-16.

9- Frentzen M, Foll V, Braun A. Photopolymerization of composite resin using LED technology. J Oral Laser Applic. 2001;1:189-194.

10- Fujibayashi M. Newly developed curing unit using blue lightemitting diodes. Dentistry in Japan. 1998;34:49-53

11- Harrington E, Shortall AC, Wilson HJ. Depth of cure of radiationactivated composite restoratives - influence of shade and opacity. J Oral Rehabil. 1995;22:337-42.

12- Ilie N, Felten K, Trixner K, Hickel R, Kunzelmann K. Shrinkage behavior of a resin-based composite irradiated with modern curing units. Dent Mater. 2005;21:483-9.

13- Kanca J 3rd. The effect of thickness and shade on the polymerization of light-activatedmposterior composite resins. Quintessence Int. 1986;17:809-11.

14- Kawaguchi M, Fukushima T, Miyazaki K. The relationship between cure depth and transmission coefficient of visible-lightactivated resin composites. J Dent Res. 1994;73:516-21.

15- Kurachi C. Estudo comparativo do laser, do LED azul e da lâmpada convencional no processo de polimerização da resina composta dental. São Carlos; 2000. [Dissertação de Mestrado - Escola de Engenharia de São Carlos da USP]. 
16- Lohbauer U, Rahiotis C, Krämer N, Petschelt A, Eliades G. The effect of different light-curing units on fatigue behavior and degree of conversion of a resin composite. Dent Mater. 2005;21:608-15.

17- Mandarino F, Porto CLA, Fontana UF, Cândido, MSM, Oliveira Jr OB. Efeito da tonalidade de cor sobre a profundidade de polimerização das resinas compostas fotopolimerizáveis. Rev Bras Odontol. 1992;49:38-41.

18- Nalcaci A, Kucukesmen C, Uludag B. Effect of high-powered LED polymerization on the shear bond strength of a lightpolymerized resin luting agent to ceramic and dentin. J Prosthet Dent. 2005;94:140-5.

19- Pereira SK, Porto CLA, Mendes AJD. Avaliação da dureza superficial de uma resina composta híbrida em função da cor, tempo de exposição, intensidade de luz e profundidade do material. JBC J Bras Clin Estet Odontol. 2000;4: 63-7.

20- Pereira SK, Porto CLA, Mendes AJD. Efeitos de diferentes sistemas de fotopolimerização na dureza superficial da resina composta. JBC J Bras Clin Estet Odontol. 2001;5(26):156-61.

21- Pires JA, Cvitko E, Denehy GE, Swift EJ Jr. Effects of curing tip distance on light intensity and composite resin microhardness. Quintessence Int. 1993;7:517-21.

22- Pollack BF, Lewis Al. Visible light resin-curing generators: a comparison. Gen Dent. 1981;29:488-93.

23- Price RB, Ehrnford L, Andreou P, Felix CA. Comparison of Quartz-Tungsten-halogen, Light-emiting Diode, and Plasma Arc Curing Lights. J Adhes Dent. 2003;5:193-207.

24- Price RBT, Corey AF, Pantelis A. Effects of resin composite composition and irradiation distance on the performance of curing lights. Biomaterials. 2004;25:4465-77.

25- Rissi RC, Cabral A. Fotopolimerização: principais vantagens clínicas que podem interferir no processo. Rev Assoc Paul Cir Dent. 2002;56:123-8.

26- Shortall A \& Harrington E. Guidelines for the selection, use, and maintenance of visible light activation units. $\mathrm{Br}$ Dent $\mathrm{J}$. 1996;180:383-7.

27- Swartz ML, Philips RW, Rhodes B. Visible light-activated resins depth of cure. J Am Dent Assoc. 1983;106:634-7.

28- Taira M, Urabe H, Hirose T, Wakasa K, Yamaki M. Analysis of photo-initiators in visible-light-cured dental composite resins. J Dent Res. 1988;67:24-8.

29- Tanoue N, Koishi Y, Matsumura H, Atsuta M. Curing depth of different shades of a photo-activated prosthetic composite material. J Oral Rehabil. 2001;28:618-23.

30- Thirta R, Fan PL, Dennison JB, Powers JM. In vitro depth of cure of photo-activated composites. J Dent Res. 1982;61:1184-7.

31- Tsai PCL, Meyers IA, Laurence JW. Depth of cure and surface microhardness of composite resin cured with blue LED curing lights. Dent Mater. 2004;20:364-9.

32- Uhl A, Mills R, Rzanny A, Jandt K. Time dependence of composite shrinkage using halogen and LED light curing. Dent Mater. 2005;21:278-86.

33- Uhl A, Sigusch BW, Jandt KD. Second generation LEDs for the polymerization of oral biomaterials. Dent Mater. 2004;20:80-7.
34- Vieira RS, Ehrardt AE, Shroeder LF. Intensidade de luz de aparelhos fotopolimerizadores utilizados em consultórios particulares. JBC J Bras Clin Estet Odontol. 1999;4:41-4. 